\title{
Obituary
}

\section{Ernest Henry Nickel 1925-2009}

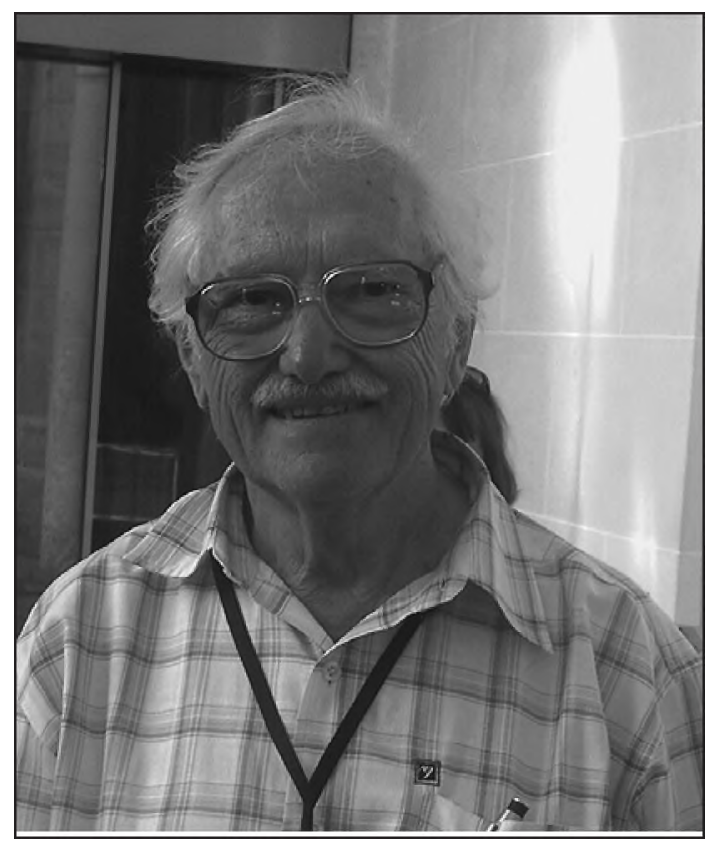

In 1985, Ernie Nickel retired as a chief research scientist from the CSIRO Division of Mineralogy in Perth, Western Australia, but retained access to the facilities of the Division as an Honorary Fellow. He was to enjoy a very active retirement, cycling to the CSIRO laboratories every day to continue his research and in particular his activities as vice-chairman of the International Mineralogical Association's Commission on New Minerals and Mineral Names (CNMMN). Ernie was to be very active in trying to tidy up mineralogical nomenclature, a task that was to occupy him for the rest of his life.

Ernest Henry Nickel was born into a farming family in Louth, Ontario Canada on 31 August 1925. His interest in minerals was sparked by visits to the Royal Ontario Museum in Toronto and he went on to study geology at McMaster University, graduating with a BSc in 1950 and MSc in 1951. He moved to the University of Chicago to study the distribution of major and minor elements among co-existing pyrite and ferromagnesian silicates using spectrographic analysis and was awarded his $\mathrm{PhD}$ in 1953. Ernie joined the Mineragraphic Laboratory of the Mines Branch, of the Canadian Department of Energy, Mines and Resources in Ottawa (now CANMET) in 1953 and over the next 18 years worked on aspects of the sulphide mineralogy of some of Canada's main nickel deposits, amongst other topics. By 1971 Ernie had become head of the Mineralogy Section of the Canadian Department of Energy, Mines and Resources and his duties were becoming increasingly administrative with little opportunity to continue hands-on research. At this point an opportunity arose to move to Commonwealth Scientific and Industrial Research Organization (CSIRO) Division of Mineralogy in Perth, Western Australia. Large nickel deposits had recently been discovered in that part of Australia and there was a need for a nickel mineralogist. Ernie had both the right name and the background and at CSIRO he had the opportunity to continue to research and at the same 
time advance in the organization without being forced into management.

For the next 14 years, until his retirement in 1985 , Ernie was actively involved in research on nickel deposits and mineralogy and published over 40 papers. These included the descriptions of half a dozen new secondary nickel minerals and it is fitting that the nickel end-member of the chalcophanite group, $\mathrm{NiMn}_{3} \mathrm{O}_{7} \cdot 3 \mathrm{H}_{2} \mathrm{O}$, was named ernienickelite in his honour in 1994.

In his retirement, the classification and nomenclature of minerals became Ernie's great passions. By nature he was never dogmatic or crusading, instead being relaxed and easy going, with a twinkle in his eye and a great sense of fun. His involvement in the IMA's CNMMN began in 1974 when he became Australia's representative and a decade later he became vice-chairman. The vice-chairman's role was traditionally to handle matters involving the redefinition and discreditation of minerals and Ernie extended these activities by developing several extensive databases. With Monte Nichols, he co-authored the MINERAL database which covers all IMAapproved and 'grandfathered' species and published the Mineralogical Reference Manual. With Dorian Smith he prepared a very extensive list of unnamed minerals (numbering in the thousands) which have been noted in the mineralogical literature but never formally described. Perhaps his greatest contribution was the 9th (and first English) edition of Strunz Mineralogical Tables published 2001. Ernie greatly extended the work, increasing the number of species covered from less than 3000 to over 4000 and making extensive revisions and modifications to the classification scheme.

Ernie was a past president and life member of the Mineralogical Association of Canada, a fellow of the Mineralogical Society of America and a fellow of the Mineralogical Society. In 2008 he was elected an Honorary Fellow of the Mineralogical Society, a fitting honour and recognition for the exceptional contribution he had made to mineralogy over half a century.

Ernie met his first wife, Muriel, while they were both studying geology at McMaster and they had three daughters. Muriel died of cancer at age 50 and Ernie later married Eileen, whom he met at a local bridge club. Ernie died on 18 July 2009 , only a few weeks after being diagnosed with cancer. In his last few weeks he busied himself trying to tidy up loose ends and faced his end philosophically. He will be a great loss to the mineralogical community in general and to his many friends and colleagues around the world.

ALLAN PRING

WiLliam D. BirCH 